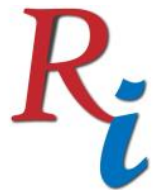

Asia Proceedings of Social Sciences

(APSS)

www.readersinsight.net/APSS

\title{
The Moderating Role of VRIN AND MEDiATING Role OF ICT ON THE RELATIONSHIP BETWEEN MANAGEMENT COMPETENCIES, ENTREPRENEURIAL ORIENTATION AND SMES PERFORMANCE
}

\section{Buba Musa Pulka*}

Division of General Studies

University of Maiduguri

Nigeria.

\section{Mohammed Alhaji Audu}

Faculty of Management Sciences, Department of Banking and Finance University of Maiduguri

Nigeria.

\section{Hauwa Aliyu Yamta}

Faculty of Management Sciences, Department of Banking and Finance University of Maiduguri

Nigeria.

*Corrosponding author's Email: bubapulka@ unimaid.edu.ng

Peer-review under responsibility of $3^{\text {rd }}$ Asia International Multidisciplanry Conference 2019 editorial board (http://www.utm.my/asia/our-team/) (C) 2019 Published by Readers Insight Publisher, lat 306 Savoy Residencia, Block 3 F11/1,44000 Islamabad. Pakistan, info@ readersinsight.net This is an open access article under the CC BY-NC-ND license (http://creativecommons.org/licenses/by-nc-nd/4.0/). 


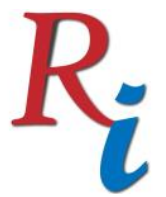

Asia Proceedings of Social Sciences

(APSS)

www.readersinsight.net/APSS

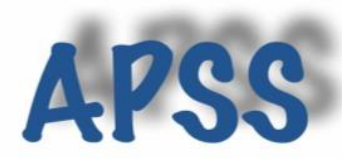

\section{Rese a r ch H i g h I igh t s}

The study is informed by inconsistencies and controversies that characterised previous research on SMEs performance that made the findings to be inconclusive. Similarly, there is a dearth of studies and understanding of the moderating role of VRIN and the mediating role of ICT resources on the relationship between management competencies, entrepreneurial orientation and SMEs performance. Therefore, these have put limits to the researchers, academics, practitioners and other stakeholders in understanding the moderating and mediating role of VRIN and ICT resources on the relationship between management competencies and entrepreneurial orientation in achieving better SMEs performance. Consequently, this paper contributes to filling in the gaps identified in the literature by developing and proposing a conceptual framework for achieving better SMEs performance, and that could explain the relationships among the various SMEs resources and SMEs performance. Therefore, the study proposed twelve propositions. Consequently, the study contributed to knowledge by providing a framework that could be used to examine the relationship between the variables of this study empirically. It also provides a basis for further/ future studies. It is hoped it would lead the achieving better SMEs performance capable of providing employment, growth of GDP, enhancing exports and standard of living of the society.

Therefore, SMEs performance is defined as the abilities of the SMEs to harness, integrate and utilize various internal and external resources with timely and right reconfiguration to achieve targeted set of objectives and performance capable of providing employment opportunities, growth of GDP, export and to uplift the standard of living of the society (Pulka, 2019). Management competencies are defined as "effective performance of a task or activity in a job setting, due to the underlying characteristics of the individual: motives, traits, skills, self-image, social role, or knowledge and experience" (LeBrasseur, Blanco, \& Dodge, 2002). Covin and Slevin (1991) defined entrepreneurial orientation as the process of development of specific behaviour that is targeted towards improving the SMEs propensity to take and absorb risks, to be creative, initiative, proactive and innovative toward achieving entrepreneurial success and a better SMEs performance. VRIN resources refer to the specific bundle of unique resources posses by the SMEs that are drivers of the SMEs' better performance (Barney, Wright, \& Ketchen, 2001). Bhakoo and Choi (2013) see ICT as "the technology-based infrastructure that acts as a conduit for facilitating transactions, sharing information with trading partners, coordinating activities and establishing governance structures between SMEs.

\section{Research Objectives}

The objectives of the study are to develop ad report a conceptual framework that would provide the basis for empirical research that answers the following research objectives; (1) examine the significant relationship between management competencies and SMEs performance. (2) examine the significant relationship between management competencies and VRIN resources. (3) examine the significant relationship between management competencies and ICT resources. (4) examine the significant relationship between entrepreneurial orientation and SMEs performance. (5) examine the significant relationship between entrepreneurial orientation and VRIN resources. (6) examine the significant relationship between entrepreneurial orientation and ICT resources. (7) examine the significant relationship between VRIN resources and SMEs performance. (8) examine the significant relationship between ICT resources and SMEs performance. (9) examine the moderating influence of VRIN resources on the relationship between management competencies and SMEs performance. (10) examine the moderating 


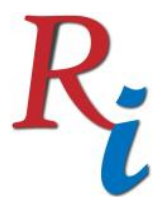

\section{Asia Proceedings of Social Sciences \\ (APSS) \\ www.readersinsight.net/APSS}

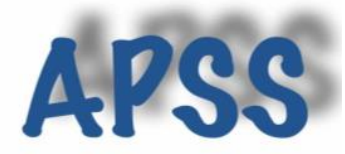

influence of VRIN resources on the relationship between entrepreneurial orientation and SMEs performance. (11) examine the mediating influence of ICT resources on the relationship between management competencies and SMEs performance. (12) examine the mediating influence of ICT resources on the relationship between entrepreneurial orientation and SMEs performance.

\section{Proposed Methodology}

To measures of management competencies, the instrument by Man (2001) can be adopted or adapted. To measure EO, the instrument can be adopted or adapted from the work of Covin and Slevin, (1989). To measure VRIN resources items can be adopted or adapted from the work of Talaja (2012). To measure ICT, the instrument can be adopted or adapted from the work of Yusuf (2013). The measure SMEs performance, the instrument can be adopted or adapted from the work Suliyanto and Rahab, (2012) or Santos and Brito, (2012).

\section{References}

Barney, J. B. (1991). Firm Resources and Sustained Competitive Advantage. Journal of Management, 17(1), 99-120. https://doi.org/10.1177/014920639101700108

Barney, J., Wright, M., \& Ketchen, D. J. (2001). The resource-based view of the firm: Ten years after 1991. Journal of Management, 27(6), 625-641. https://doi.org/10.1016/S01492063(01)00114-3

Bhakoo, V., \& Choi, T. (2013). The iron cage exposed: Institutional pressures and heterogeneity across the healthcare supply chain. Journal of Operations Management, 31(6), 432-449. https://doi.org/10.1016/j.jom.2013.07.016

Bourne, M., Neely, A., Mills, J., Platts, K., Bourne, M., Neely, A., ... Platts, K. (2003). Implementing performance measurement systems: a literature review. Int. J. Business Performance Management, 5(1), 1-24. https://doi.org/10.1504/IJBPM.2003.002097

Covin, J. G., \& Slevin, D. P. (1991). A conceptual model of entrepreneurship as firm behavior. Entrepreneurship: Critical Perspectives on Business and Management, 3, 5-28.

Covin, Jeffrey G, \& Slevin, D. P. (1989). Strategic Management of Small Firms in Hostile and Benign Environments. Strategic Management Journal, 10(1), 75-87.

Helfat, C. E., \& Peteraf, M. A. (2003). The dynamic resource-based view: Capability lifecycles. Strategic Management Journal, 24(10 SPEC ISS.), 997-1010. https://doi.org/10.1002/smj.332

LeBrasseur, R., Blanco, H., \& Dodge, J. (2002). Competences of ceos in technology-oriented sme: An exploratory study of skills for survival \& initial growth. Halifax: Laurentian University.

Man, T. W. Y. (2001). Entrepreneurial Competencies and the Performance of Small and Medium Enterprises in the Hong Kong Services Sector.

Miller, D. (1983). The Correlates of Entrepreneurship in Three Types of Firms. Management Science, 29(7), 770-791.

Pulka, B. M. (2019). The Determinants of SMEs Performance in Nigeria; The Moderating Role of External Environment. PhD Thesis Submittted to Universiti Utara Malaysia. Universiti Utara Malaysis.

Santos, J. B., \& Brito, L. A. L. (2012). Toward a subjective measurement model for firm performance. BAR - Brazilian Administration Review, 9(SPL. ISS), 95-117. https://doi.org/10.1590/S180776922012000500007

Suliyanto, \& Rahab. (2012). The role of market orientation and learning orientation in improving innovativeness and performance of small and medium enterprises. Asian Social Science, 8(1), 134-145. https://doi.org/10.5539/ass.v8n1p134

Talaja, A. (2012). Testing VRIN Framework: Resource Value and Rareness as a source of Competitive Advantage and Above Average Performance. Management, 17(2), 51-64. https://doi.org/10.1017/CBO9781107415324.004

Yusuf, A. A. (2013). Impact of ict on smes - Case Rwanda. Turku University Of Applied Sciences. 